\title{
Komplikasi Penderita Sirosis Hati di RSUD Koja pada Bulan Juli-November 2017
}

\author{
Suzanna Ndraha ${ }^{1}$, Imelda $^{2}$, Marshell Tendean ${ }^{2}$, Mardi Santoso $^{2}$ \\ ${ }^{1}$ SMF Penyakit Dalam RSUD Koja \\ ${ }^{1,2}$ Staf Pengajar Bagian IPD, Fakultas Kedokteran Universitas Krida Wacana \\ Alamat Korespondensi: susanndraha@gmail.com
}

\begin{abstract}
Abstrak
Sirosis merupakan tahap akhir dari berbagai penyakit hati kronis. Penyebab tersering adalah infeksi virus hepatitis $\mathrm{B}$, virus hepatitis $\mathrm{C}$ dan alkohol. Sirosis hati dengan komplikasinya merupakan masalah kesehatan yang masih sulit diatasi. Hal ini ditandai dengan angka kesakitan dan kematian yang tinggi. Penelitian ini bertujuan untuk mengetahui karakteristik dan komplikasi apa saja yang didapatkan pada pasien sirosis hati yang dirawat di RSUD Koja. Penelitian ini menggunakan rancangan penelitian observasional deskriptif, dengan mengambil pasien rawat inap Penyakit Dalam RSUD Koja selama Juli-November 2017. Didapatkan sebanyak 63 pasien yang terdiri dari 41 orang $(65,1 \%)$ laki-laki dan 22 orang (34,9\%) perempuan, usia 20-40 tahun sebanyak 11 orang $(17,5 \%)$, usia 40-60 tahun 46 orang $(73 \%)$, dan usia lebih dari 60 tahun 6 orang $(9,5 \%)$. Keluhan utama terbanyak adalah perut membesar (40\%). Stigmata sirosis terbanyak adalah ikterus (51\%), dan komplikasi terbanyak adalah asites, pada 55 orang $(87,3 \%)$. Hal ini memberikan kesan penting sekali melakukan evaluasi pada pasien dengan penyakit hati kronis khususnya hepatitis B mengenai kemungkinan sirosis hati.
\end{abstract}

Kata kunci: Sirosis hati, gender, usia, komplikasi

\section{Complications of Liver Cirrhosis at Koja Hospital in July-November 2017}

\begin{abstract}
Liver cirrhosis is a typical end stage of chronic liver disease. The most common causes of liver cirrhosis include hepatitis $B$ or $C$ viruses, and alcohol. Liver cirrhosis and its complications have become a difficult health problem with a high rate of morbidity and mortality. The aim of this study is to know the characteristics and complications caused by liver cirrhosis among patients at Koja Hospital. The data was obtained based on a descriptive observational study of the patients' records, taken from the Internal Medicine Department of Koja Hospital from July-November 2017. An overall of 63 patients were studied, 41 (65,1\%) males and 22 (34,9\%) females. Of the subjects, 11 (17.5\%) were 20-40 years, $46(73 \%)$ of $40-60$ years and $6(9.5 \%)>60$ years. The most common symptom was abdominal distention (40\%), whereas the most common sign was jaundice (51\%), and the most common complication was ascites (87,3\%). The study concludes that the majority of patients with liver cirrhosis at Koja Hospital was male, age within 40-60 years old, and the most common complication was ascites. These findings may give some insight about the importance of evaluation patients with chronic liver disease, spesifically hepatitis B for the possibility of liver cirrhosis.
\end{abstract}

Keywords: Liver cirrhosis, gender, age, complications 


\section{Pendahuluan}

Sirosis hati merupakan terjadinya kerusakan pada struktur hati dan fungsinya, sebagai penyakit hati tingkat akhir yang terjadi ketika jaringan parut atau fibrosis menggantikan jaringan hati yang sehat. ${ }^{1}$ Sirosis ditimbulkan dari berbagai mekanisme kerusakan pada hati yang menyebabkan terjadinya reaksi nekro inflamasi dan mekanisme perbaikan luka. ${ }^{1}$ Secara histologi, sirosis hati dikarakteristikkan sebagai regenerasi difus nodular yang dikelilingi oleh septa fibrotik padat dengan menghilangnya beberapa parenkim dan kolapsnya struktur hati, bersama-sama membentuk distorsi dari vaskularisasi hepatik. ${ }^{2}$

Pasien dengan sirosis hati biasanya memiliki beragam keluhan berdasarkan tingkat keparahan sirosis, dari sirosis bersifat dini atau terkompensasi, adanya hipertensi porta serta kegagalan fungsi hati akibat proses kronik aktif. $^{2}$ Sebagian sirosis hati yang terkompensisasi sempurna bersifat asimptomatis, sehingga pada umumnya pasien tidak mengetahui mengenai penyakitnya sebelum melakukan pemeriksaan menyeluruh. Akan tetapi, bisa juga timbul keluhan yang tidak khas seperti merasa badan tidak sehat, kurang semangat untuk bekerja, rasa kembung, mual, mencret kadang sembelit, tidak selera makan, berat badan menurun, otot-otot melemah, dan rasa cepat lelah. ${ }^{2-4}$ Keluhan yang timbul baik itu sedikit atau banyak tergantung dari luasnya kerusakan pada parenkim hati. ${ }^{3}$ Apabila timbul kuning pada kulit maka dipastikan sedang terjadi kerusakan sel hati. Tetapi, jika sudah masuk ke dalam fase dekompensasi maka gejala yang timbul bertambah dengan gejala dari kegagalan fungsi hati dan adanya hipertensi porta. ${ }^{2,5}$

Sirosis hati dapat menimbulkan berbagai komplikasi yang mempengaruhi tingkat morbiditas dan mortalitas. Beberapa komplikasi tersering dari sirosis hati adalah hipertensi porta, asites serta pendarahan varises. $^{2}$ Beberapa komplikasi lain juga ditemukan pada pasien dengan sirosis hati walaupun secara statistik tidak sesering komplikasi hipertensi porta, asites dan pendarahan varises. Dapat terjadi hepatik ensefalitis dengan gejala gangguan kognitif terkait dengan sirosis. ${ }^{6}$ Dapat terjadi trombosis vena porta pada pasien sirosis dekompensata. ${ }^{7}$ Selain itu gagal ginjal akut yang merupakan salah satu komplikasi paling parah yang dialami oleh pasien sirosis dan biasanya sudah didahului oleh komplikasi pendarahan varises dan peritonitis bakterial spontan. ${ }^{8}$

\section{Metoda}

Penelitian ini menggunakan rancangan penelitian observasional deskriptif. Target populasi dalam penelitian ini adalah seluruh pasien sirosis hati di RSUD Koja. Populasi terjangkau adalah semua pasien rawat jalan dan rawat inap Bagian Penyakit Dalam RSUD Koja Jakarta selama Juli-November 2017 yang didiagnosis dengan sirosis, berusia 20-70 tahun, dan tidak dalam komplikasi akut. Data akan disajikan dalam bentuk tabel dan grafik untuk menggambarkan karakteristik pasien sirosis hepatis dengan komplikasinya.

\section{Hasil}

Telah dilakukan penelitian selama JuliNovember 2017, dan didapatkan sebanyak 63 pasien dengan jenis kelamin terbanyak adalah laki-laki 41 orang $(65,1 \%)$. Berdasarkan usia pasien proporsi terbanyak adalah pasien berusia 40-60 tahun sebanyak 46 orang (73\%). Kebanyakan pasien berkonsultasi atau mengalami perawatan oleh karena perut yang membesar dan mengalami komplikasi asites yaitu sebanyak 55 orang $(87,3 \%)$, sebagaimana terlihat pada tabel 1.

Berdasarkan etiologi penyakit Sebanyak 37 pasien $(59 \%)$ didapatkan mempunyai penyakit hati kronik, dengan proporsi terbanyak pada pasien yang terinfeksi hepatitis B 34 orang (92\%).

\section{Pembahasan}

Proporsi jenis kelamin penelitan ini sesuai dengan penelitian yang dilakukan Romania ditemukan prevalensi laki-laki yang juga menemikan sirosis hati $(65,3 \%)$ lebih banyak daripada perempuan $(34,7 \%){ }^{9}$ Demikian pula pada penelitian yang dilakukan di Tanzania juga menemukan prevalensi lakilaki lebih banyak dibandingkan perempuan (78,4 \% berbanding 21,6\%). ${ }^{10}$

Penelitian ini membagi pasien menjadi tiga kelompok umur. Berdasarkan pembagian kelompok umur prevalensi paling tinggi didapatkan pada kelompok usia 40-60 tahun (73\%). Sesuai dengan hasil penelitian yang 
dilakukan di Romania, yaitu distribusi usia tertinggi pada kelompok berusia 51-60 tahun $(41,1 \%)$. Hasil ini tak jauh berbeda dengan penelitian yang dilakukan di Tanzania juga dengan data populasi pasien sirosis hati ratarata berumur 36-60 tahun (52,3\%).

Keluhan utama yang didapatkan adalah perut membesar, diikuti oleh buang air besar. Keluhan lainnya yang dirasakan pasien yaitu kulit berwarna kuning, lemas, mual, nyeri perut, dan sesak dimana masing-masing keluhan tersebut dibawah 10 orang. Namun, penelitian ini menemukan prevalensi keluhan perut membesar yang lebih rendah daripada penelitian di India, yang menunjukan kemungkinan kasus di Indonesia ditemukan dalam tahapan lebih dini. ${ }^{11}$

Dari hasil penelitian ini juga didapatkan faktor predisposisi atau komorbid yang paling banyak adalah penyakit hati kronis, dengan etiologi penyakit hati kronis secara beruturutturut hepatitis B dan hepatitis C.

Hasil penelitian ini sesuai dengan penelitian di Singapura, yaitu didapatkan penyebab sebagai terbanyak sirosis hati hepatitis B $(66,4 \%) .{ }^{3,6}$ Selain itu, penelitian yang dilakukan di Cina Selatan mendapatkan penyebab terbanyak sirosis hati adalah virus hepatitis $(80,62 \%)$, yaitu hepatitis B sebanyak $(77,22 \%)$, dan hepatitis C sebanyak (2,80\%), disusul alkohol $(5,68 \%){ }^{12,13}$ Stigmata sirosis yang terbanyak adalah ikterus diikuti oleh edema. Pada penelitian yang dilakukan di China didapatkan stigmata terbanyak ditemukan adalah ikterus (58\%); hal ini sesuai dengan hasil penelitian kami. ${ }^{13}$

Jenis komplikasi paling banyak adalah asites, anemia, dan pendarahan esophagus. Penelitian di Turki menemukan komplikasi terbanyak dari pasien sirosis hati dekompensata adalah asites, diikuti pendarahan varises esophagus, dan spontaneous bacterial peritonitis (SBP). ${ }^{14}$

Pasien sirosis hati menurut klasifikasi Child Pugh terbanyak adalah Child Pugh C (50,8\%) diikuti oleh Child Pugh B (30,2\%). Hal ini sesuai dengan penelitian yang dilakukan di Turki, yang menemukan pasien sirosis hati yang tergolong dalam Child Pugh C (53\%), Child Pugh B (32\%) dan Child Pugh A $(15 \%)$. Ini menjadi tanda bahwa sebagian besar pasien yang datang sudah memiliki derajat penyakit yang berat. Sirosis merupakan penyakit yang menggambarkan stadium akhir fibrosis hepatik yang berlangsung progresif dan umumnya bersifat laten sehingga pada fase awal tidak ditemukan adanya gejala. Sampai saat ini yang paling populer dipakai sebagai parameter dalam upaya menentukan prognostik sirosis hati adalah kriteria child yang dikaitkan dengan kemungkinan menghadapi operasi. ${ }^{1,14}$

Tabel 1. Karakteristik dan Komplikasi Pasien Sirosis Hati Rawat Inap dan Rawat Jalan di RSUD Koja Juli-November 2017

\begin{tabular}{|c|c|}
\hline Karakteristik & $n *(\%)$ \\
\hline \multicolumn{2}{|l|}{ Jenis Kelamin } \\
\hline Laki-laki & $41(65,1 \%)$ \\
\hline Perempuan & $22(34,9 \%)$ \\
\hline \multicolumn{2}{|l|}{ Umur } \\
\hline 20-40 tahun & $11(17,5 \%)$ \\
\hline $40-60$ th & $46(73 \%)$ \\
\hline diatas 60 th & $6(9,5 \%)$ \\
\hline \multicolumn{2}{|l|}{ Keluhan Utama } \\
\hline Perut membesar & $25(39,7 \%)$ \\
\hline Buang air besar hitam & $16(25,4 \%)$ \\
\hline Nyeri perut & $7(11,1 \%)$ \\
\hline Sesak & $6(9,5 \%)$ \\
\hline Mual & $5(7,9 \%)$ \\
\hline Lemas & $3(4,8 \%)$ \\
\hline Mata kuning & $1(1,6 \%)$ \\
\hline \multicolumn{2}{|l|}{ Predisposisi/komorbid } \\
\hline Penyakit hati kronis & $37(58,7 \%)$ \\
\hline $\mathrm{DM}$ & $13(20,6 \%)$ \\
\hline Alkohol & $7(11,1 \%)$ \\
\hline Tidak Ada & $6(9,5 \%)$ \\
\hline \multicolumn{2}{|l|}{ Stigmata Sirosis } \\
\hline Ikterus & $32(51 \%)$ \\
\hline Edema dan Ikterus & $28(44 \%)$ \\
\hline Edema & $2(3 \%)$ \\
\hline Spider Nevi & $1(2 \%)$ \\
\hline Eritema Palmaris & $\begin{array}{l}1(2 \%) \\
0(0 \%)\end{array}$ \\
\hline Vena Kolateral & $0(0 \%)$ \\
\hline \multicolumn{2}{|l|}{ Jenis Komplikasi } \\
\hline Asites & $55(87,3 \%)$ \\
\hline Anemia & $38(60,3 \%)$ \\
\hline Varises Esofagus & $15(23,8 \%)$ \\
\hline Hepatoma & $4(6.4 \%)$ \\
\hline \multicolumn{2}{|l|}{ Child Pugh } \\
\hline A & $12(19 \%)$ \\
\hline B & $19(30.2 \%)$ \\
\hline $\mathrm{C}$ & $32(50,8 \%)$ \\
\hline
\end{tabular}

*Data numerik disajikan dalam mean $\pm \mathrm{SD}$, data kategorik disajikan dalam n(\%) 


\section{Simpulan}

Mayoritas pasien sirosis hati yang dirawat di RSUD Koja adalah laki-laki dengan keluhan utama perut membesar, dan proporsi terbanyak pada hepatitis B. Hal ini menandakan pentingnya melakukan evaluasi pada pasien penyakit hati kronis khususnya hepatitis B untuk kemungkinan terjadi sirosis hati.

\section{Daftar Pustaka}

1. European Association for the Study of the Liver (EASL). Background media information : fast fact about liver diease. [Online]. 2016; [4 screens]. Diunduh dari: http://2016.ilc-congress.eu/wp-content/ uploads/2016/04/ Liver-diseasebackgrounder.pdf. 24 Juni 2017

2. Tsochatziz EA, Basch J, Burroughs AK. Liver cirrhosis. The Lancet. 2014;1-8.

3. World Health Organization (WHO). Indicator code book: global information system on alcohol and health. [Online]. 2014;4-2.

http://www.who.int/substance_abuse/acti vities/gisah_indicatorbook.pdf. 24 Juni 2017

4. Wang FS, Fan JG, Zheng Z, Gao B, Wang HY, The global burden of liver disease: the major impact of China. J Hepatology. 2014; 2099-108.

5. Klien S, Rick J, Lehmann J ,Schierwagen $\mathrm{R}$, Schierwagen IG, Verbeke L, et al. Janus - kinase -2 relates directly to portal hypertension and to complications in rodent and human cirrhosis. Gut. 2015;66(1):145-55.

6. Sarma SM, Yachha SK, Bhatia V, Srivastava A, Poddar U. Safety, complication and outcome of large volume paracentesis with severe ascites due to liver disease. J Hepatology. 2015;63(5):1125-33.

7. Waidmann O, Brunner F, Herrmann E, Zeuzem S, Piiper A, Kronenberger B.
Macrophage activation is a prognostic parameter for variceal bleeding and overall survival in patients with liver cirrhosis. J Hepatology. 2013;58(5):95661.

8. Vilstrup H, Amodio P, Bajaj J. Hepatic encepalophaty in chronic liver disease : 2014 practice guideline by the american association for the study of liver disease and the european association for the study of the liver. J Hepatology. 2014: 8-6.

9. Nicoleta S, Ligia, Corina U, Maria B, Lonela S, Marius C, Grigore D. The prevalence of chronic liver disease: implications for renal impairment. Acta Med Marisiensis. 2015;61(3):168-71.

10. Raphael KC, Matuja SS, Shen NT, Liwa AC, Jaka H. Hepatic encephalopathy; prevalence, precipitating factors and challenges of management in a resourcelimited setting. J Gastrointestinal \& Digestive System. 2016;6:441.

11. Archarya S, Shukla S, Buthada G, Rautray K. Hematological abnormalities in cirrhosis of liver. Indian J. 2017;7(3): 168-2.

12. Chang PE, Wong GW, Li JW, Lui HF, Chow WC, Tan CK. Epidemiology and clinical evolution of liver cirrhosis in Singapore. Annals Acad of Med. 2015;44(6):218-7.

13. Wang $X$, Lin SX, Tao J, Wei XQ, Liu YT, Chen YM, and Wu B. Study of liver cirrhosis over ten consecutive years in Southern China. World J Gastroenterol. 2014;20(37):13546-9.

14. Topdagi O, Okcu N, Bilen N. The frequency of complications and the etiology of disease in patients with liver cirrhosis in Ezurum. J Med. 2014; 46(2):110-14.

15. Hutahaean R, Ali RH, Loho E. Hubungan gambaran USG pada penderita sirosis hati dengan fibrosis skor di bagian radiologi RSUP Prof Dr R.D. Kandou Manado pada bulan Januari 2013 Desember 2013. E-Clinic. 2014;2(1):3-4. 